\title{
Forced Marriage, Slavery, and Plural Legal Systems: An African Example
}

\author{
Jody Sarich, * Michele Olivier** \& Kevin Bales***
}

* Jody Sarich has seventeen years experience in research and advocacy of historical and contemporary slavery. She is the former Director of Research for the US-based international antislavery nonprofit Free the Slaves, where she oversaw participatory impact evaluation studies of antislavery interventions in India and Haiti and prevalence studies of slavery and forced labor in mining zones of Eastern Democratic Republic of Congo. She is currently working on a book, with Kevin Bales, about forced marriage based on her collection of the life narratives of forced marriage survivors and grassroots activists around the world, fiscally sponsored by Voices4Freedom Foundation. She received her M.A. in African History in 1999 from the School of Oriental and African Studies (SOAS), London, her J.D. from DePaul University School of Law in 2010, and is completing her Ph.D. thesis in African History on slavery in the Cape Colony. She was a member of the International Research Network to Define Slavery in International Law, sponsored by Queen's University, Belfast and the International Workshop on Forced Marriage in Conflict Situations, sponsored by York University, Toronto, and was on the advisory panel for the Global Slavery Index sponsored by the antislavery organization Walk Free. She has represented women seeking asylum in the United States and legal status under the Convention against Torture and has served as an expert witness for women who sought asylum in the US after having fled forms of enslavement in their home countries.

** Michèle Olivier is a reader at the School of Politics, Philosophy and International Studies, University of Hull. She obtained her LL.B. and B.A. (Hons) (Political Science) degrees from the University of Pretoria in 1986. She then completed her article clerkship and was subsequently admitted as an attorney in South Africa in 1989. In the same year, she obtained an M.A. degree in Political Studies on the relativity of human rights in African states, from the Rand Afrikaans University. She was appointed by the Department of Foreign Affairs in South Africa as a State Law Adviser in the Office of the State Law Adviser (International Law) in 1989 and is admitted as an advocate. An LL.M. degree in Public International Law was conferred on her in 1991 by the University of Pretoria. In 1995, she was promoted to the position of Principal State Law Adviser in the Department of Foreign Affairs, where she represented the South African government in the negotiating of treaties, participated in various committees of the United Nations and provided international law advice to the South African government. An LL.D. degree was conferred on her by the University of South Africa in 2002. Her research focused on the status and implementation of international law in South African law. Before relocating to the United Kingdom in 2009, she was a professor in the Department of Public Law at the University of Pretoria (2002-2009). She was one of eight members of the Technical Committee of Constitutional Experts responsible for the drafting of the South African Constitution of 1993. She has acted as a consultant to the African Peer Review Mechanism (ARPM) of the Africa Union with respect to Malawi, Kenya, Mozambique, and South Africa.

***Kevin Bales is Professor of Contemporary Slavery at the Wilberforce Institute for the Study of Slavery and Emancipation, University of Hull; and a lead author of the Global Slavery 


\begin{abstract}
Slavery, long abolished under international law, left a devastating imprint on Africa. However, enslavement of women through forced marriages remains a common phenomenon in many African states. These African states share the common feature of legal pluralism where traditional legal systems continue to be observed alongside national laws in which slavery is outlawed. Where traditional practices condone the marriage of underage girls who are legally unable to consent, the questioning of age-old accepted forms of marriage can generate strong reactions. This article traces the position of forced and child marriages in international law, and investigates how legality becomes a moveable target when legal systems exist in parallel. Despite international and African Union conventions on slavery and human rights declaring that marriages not based on the full and free consent of both parties are considered a violation of human rights and a form of slavery, these practices persist. These instruments are assessed to gauge the level of conformity (or variance) of African state practice where forced marriages commonly occur. Importantly, the reasons behind noncompliance and the impact of legal pluralism are explored in African states where forced marriages commonly occur.
\end{abstract}

\title{
I. INTRODUCTION
}

Forced marriage is, arguably, the most common and the least understood form of enslavement of women, both historically and today. It is a form of slavery almost entirely feminized and yet, unlike other forms of slavery, it has not been the target of the same legal and cultural responses and prohibitions afforded the forms of enslavement where men are included. Equally, it is an area of slavery that is global in its reach, and yet is little understood and studied. This article explores the international legal context that addresses forced marriage in Africa, and its relationship with plural, sometimes referred to as parallel, legal systems on that continent. ${ }^{1}$ It will demonstrate a

Index. He was CoFounder of the NGO Free the Slaves (www.freetheslaves.net). His book Disposable People: New Slavery in the Global Economy published in ten languages, was named one of " 100 World-Changing Discoveries" by the Association of British Universities. The film version won a Peabody and two Emmys. Bales has advised the US, British, Irish, Norwegian, and Nepali governments on trafficking and slavery policy. His book Ending Slavery: How We Free Today's Slaves, won the Grawemeyer Prize (2007). He also published To Plead Our Own Cause: Personal Stories by Today's Slaves (2008) with Zoe Trodd; Documenting Disposable People with eight Magnum photographers; and The Slave Next Door: Modern Slavery in the United States (2009) with Ron Soodalter. His newest book, Blood and Earth: Modern Slavery, Ecocide, and the Secret to Saving the World was published in January 2016.

1. The existence of traditional or religious legal systems alongside the official or national legal system in place in a particular state is sometimes referred to as "parallel legal systems." For purposes of this discussion, the term "plural legal systems" is used, and the term "customary law" refers to traditional law. 
significant relationship between this type of enslavement and the presence of plural legal systems, and point to areas of further needed research.

There is no reliable estimate of the number of adult women or girl children enslaved in forced marriages globally, or in any single region or country. Indeed, in many cultures forced marriages are not defined as such, in spite of clearly violating the criteria in, for example, the 1956 UN Slavery Convention. ${ }^{2}$ Required minimum age at marriage varies from country to country, and often goes unenforced. Subgroups within many societies jealously guard the "right" to marry off girls despite protests against it, and when they do so, this practice is often overlooked or condoned by governments as an ethnic or cultural practice. This relativist interpretation of human rights opens the door to the commoditization of children. As Mike Dottridge notes:

In some cultures it is still common for girls to be abducted by the bridegroom or his relatives, for example in parts of Bénin and Ethiopia. In others, notably in China, it is common for an intermediary to be involved in the abduction, in order to make a profit by delivering a young woman to her prospective husband: in this case it qualifies as trafficking. In addition to abducting women for marriage, however, marriage agents play a role in many societies in negotiating marriages and are remunerated for their efforts. On the whole this traditional role is regarded as perfectly acceptable. ${ }^{3}$

Research on forced marriage faces two powerful obstacles. Firstly, such research violates a strong and widespread social belief that marriage should be unquestioned and untouchable, and that inquiry into, and discussion of marriage threatens social stability. Secondly, such research must confront the rationale that forced marriage simply reflects valid cultural norms. There is an ideological undercurrent within most societies that insists that while many aspects of social life might change, marriage is untouchable. In those countries that have interlocking systems of state, customary, and tribal law, traditional forms of marriage have even greater insulation against change. This means that while some forms of traditional inheritance patterns are protected, it can also mean that cases of forced marriage are concealed behind a veneer of normative cultural practice.

Much of the current debate and controversy about marriage in many societies today rages not over the forms or expressions of marriage, but simply over whether marriage can be altered at all. In a sense, the debate concerns whether the question is even open to debate, and restricting the focus to this point distracts from more pertinent and fundamental issues.

2. Supplementary Convention on the Abolition of Slavery, Slave Trade and Institutions of Similar Practices, adopted 7 Sept. 1956, 226 U.N.T.S. 3 (entered into force 30 Apr. 1957).

3. Mike Dottridge, Terre des Hommes, Kids as Commodities? Child Trafficking and What to do Aвоuт Iт 25 (2004). 
Foremost amongst these is the need for a clear understanding of how marriage, particularly forced marriage, is an identity and status externally fixed upon an individual. Whether through codified or customary law, the extensive social and legal controls over marriage mean that it is a status rigidly fixed and guarded. For the woman who has been forced into marriage, her enslavement is concealed by both her legal status as a "wife" and by a great fog of cultural practice and pronouncement describing this subjugation as "normal." It is in the interest of those who are supportive of and benefit from forced marriage to present it simply as a form of cultural expression, just one more legitimate custom within the great diversity of human activity. To focus any consideration of forced marriage firstly on the idea that discussion of marriage is an untouchable topic, and secondly on the rationale that it is simply a form of marriage reflecting valid cultural norms, diverts attention from the key point, that of status, and the use of legal status to subjugate another human being. Put simply, given its support in customary law in many countries, forced marriage is the last legal slavery.

In Africa, as in many other contexts around the globe, forced marriage exists in both the past and in the present. In the period immediately after the end of legal slavery in Africa, the effective difference between the purchase of a female slave and the payment of bridewealth was often fraught with ambiguity. ${ }^{4}$ After the abolition of legal slavery, former male masters, eager to retain the labor potential and sexual availability of their former female slaves, were clever enough to understand that by reframing their previous labor and sexual relations within the institution of customary marriage, they would legally retain the same levels of control they had always enjoyed. It would not have surprised those present at the time that the payment by a man of bridewealth to secure an unwilling former slave bride was an attempt to repurchase within the new legal framework of marriage the person who had previously been his property under the framework of legal slavery. The woman herself was aware that this was not a marriage at all, but rather a mechanism to legitimize her enslavement within a different, legally-binding social institution. There is evidence that some of these nonconsenting brides were able to secure divorces in court. ${ }^{5}$ It is assumed that others were not. It is to those women who were prevented through violence, or its threat, from walking away from the marriage that enslaved them, that attention should be most closely drawn, though it is virtually impossible to find these women's voices in the historical record.

\footnotetext{
4. For examples within Colonial French West Africa, see Richard L. Roberts, Voices of Slavery in the Colonial Courts of French West Africa in the Aftermath of Slavery, Paper presented at the Tales of Slavery: Narratives of Slavery, the Slave Trade, and Enslavement in Africa Conference, (Toronto, 20-23 May 2009).

5. Id.
} 
However, the voices of women today who share similar stories are perhaps our truest guides to the enslavement and trafficking of women and children in forced marriages in contemporary Africa. Note as an illustrative example the well-documented case of "Evie" ${ }^{6}$ from Nigeria, whose father promised her to be the youngest bride of a village elder in exchange for money and political influence. The first time Evie met this man, she begged him to reconsider-after all, the ceremony had not yet taken place. He raped her to demonstrate the certainty of his purchase. When she told her parents of the assault, her shame was met by her father's bitter warning that if she continued to resist, the village elders would bury her alive. Neither her father nor the elders expected to suffer any consequences for her murder, since they were simply upholding honor within the community. Her father made it very clear to Evie that there was no escape from this marriage. The transaction agreement had taken place when she was a very young child. The bride price was paid.

The difference between the legal purchase of an unwilling slave and the legally-enforceable payment of bridewealth to gain an unconsenting bride is no less ambiguous today than it was then. The key difference is the fact that slavery is now illegal in terms of national and international law, as will be explored below. Yet legality becomes a moveable target when legal systems exist in parallel and view certain actions, such as marriage, in different ways. In those African states where traditional (also referred to as customary) legal systems exist side by side with formal government structures, codified and common law there is often not a clear distinction between common law and religious and traditional practices. The inevitable overlap between cultural, traditional, and religious practices as well as national legislation in many African states has the power to exert extra-legal control over the lives of young women and girls. ${ }^{7}$

Marriage is a social institution often regulated by both traditional and codified law. Religious control plays an important role in many, if not most, cultures and societies, and it is to be expected that any alteration or questioning of the forms of marriage that are accepted or required by religious dogma might elicit an extreme reaction. Even a number of those contemporary states that purport to most deeply value individual human rights and choice are, at the time of writing, caught up in controversy over the control of marriage.

6. Jody Sarich \& Kevin Bales, Gaining Freedom Through a "Well-Founded Fear:" Uncovering the Voices of Modern Slaves in Asylum Applications in the United States, Paper presented at the Tales of Slavery: Narratives of Slavery, the Slave Trade and Enslavement in Africa Conference, (Toronto, 21 May 2009).

7. For a discussion of the differences between customary law and common law see J.C. Bekker \& Christa Rautenbach, Nature and Sphere of Application of African Customary Law in South Africa, in Introduction to Legal Pluralism in South Africa 23 (Christa Rautenbach et al. eds., 2010). 
Many citizens of Western European and North American countries that are known for their breadth of civil liberties and the separation of religion and state continue to deny the right to legal marriage to some individuals because of their choice of spouse. In these countries, legal challenges have been met with popular and electoral outrage, communities have been polarized, and conflict has resulted.

In the same way, in many African countries the act of questioning the accepted forms of marriage can generate equally strong reactions, and actions and opinions not in line with cultural norms are often criminalized. All of this points to the extreme sensitivity across cultures when forms of marriage $^{8}$ are questioned. This reflects an ideological undercurrent within most societies as powerful as the one that once guarded the legality of chattel slavery or the exclusion of women from full citizenship. There is a strong insistence that while many aspects of social life might change, marriage is sacrosanct. In the African context, traditional forms of marriage, often bracketed by interlocking systems of state, customary, and tribal law, have even greater insulation against change. In African traditional law, various aspects of an individual's life are interlinked with that of their community. The importance of community and the ideal of shared humanity as embodied in the notion of ubuntu, for example, are used to protect the individual from harm. ${ }^{9}$ This means that while some forms of traditional property ownership and inheritance patterns prevail, cases of forced marriage are concealed behind a veil of normative cultural practice. That veil needs to be pierced in order to understand how forced marriage has an impact on the identity, status, life chances, and lived experiences of individual women.

\section{CHILD AND FORCED MARRIAGE IN INTERNATIONAL LAW}

We find ourselves in an important era in history in which legal slavery no longer exists and laws against slavery exist everywhere. Yet, having reached this era in which antislavery laws are in place, we must continue to face the critical, and often humbling, question of why these laws often do not operate in a more meaningful way, both in domestic courts and international

8. Within the social sciences, marriage and family are regarded as making up one of the five fundamental social institutions. The other four are: government, religion, economic exchange, and education. A social institution is a patterned activity that has been found in all human societies. Clearly, this is not to say that all religions or forms of government are identical across space and time- only that some forms of government or some forms of religion have been found in all human societies. The forms of marriage and family life also vary significantly across different societies, and what is accepted or required in one culture, may be forbidden in another.

9. S v. Makwanyane 1995 (6) BCLR 665 (CC), ๆ 9 307-08 (S. Afr.) 
tribunals, particularly in regard to women and girls who face forced marriage. Part of the answer to this question naturally lies in the ability of law enforcement to bring perpetrators to prosecutors, but it is also ultimately found in the manner in which the crime of forced marriage, and ultimately the crime of slavery itself, is defined, understood, and ultimately applied by the judicial process. Because the law enforcement and judicial process is comprised ultimately of individuals who bring their own understandings of the world to work with them, we must also always seek to understand the ways in which legal definitions of slavery shape the larger public understanding of the crime of slavery, both internationally and domestically.

To trace the recognition of forced and child marriages in international law, it is important to do an audit of the legal measures in place. Such an exercise will reflect those aspects on which the international community has consensus, but also examines the regulatory framework in place-the rules that states need to adhere to. Against this background the following questions will be considered: What is a "child marriage?" What is a "forced marriage?" Are child marriages necessarily forced marriages? Can involuntary marriages be considered a form of slavery?

It is necessary for the purposes of this article to establish which African states are bound by conventions regulating marriage, slavery, and human rights. The official websites of the African Union (AU) ${ }^{10}$ and United Nations $(\mathrm{UN})^{11}$ are relied on for the gathering of such information. For purposes of this research, it is important to gauge the level of conformity or variance of state practice with the international instruments to which they are committed.

The issues of child and forced marriage are not confined to a single international instrument. Instead, the regulation of child marriage through international law requires reading together different instruments, dating as far back as 1926, that deal with a wide range of topics from slavery to children's rights. Identification and explanation of applicable provisions are important from a methodological perspective because this will define the terrain, and identify shortcomings in the regulatory environment. The next step assesses whether and to what extent these provisions are enforced in practice and the nature of the legal systems where these practices commonly occur.

A growing body of scholarship has begun to address the question of whether forced or servile marriage is a violation of international law against slavery, incurring state and even individual liability. ${ }^{12}$ With few exceptions,

10. African Union, available at http://au.int/en/treaties.

11. United Nations, United Nations Treaty Collection, available at https://treaties.un.org/.

12. See Jean Allain, The Definition of Slavery in International Law, Howard L. J. 239 (2009); Jean Allain, The Legal Understanding of Slavery: From the Historical to the Contemporary (2012); Kevin Bales \& Jody Sarich, Slavery and Servitude in Contemporary Jurisprudence, Paper presented to Slavery as the Powers Attaching to the Right of Ownership, Bellagio, Italy 2010); Kevin Bales \& Jody Sarich, Afterword, in Trafficking in Slavery's Wake: Law and the Experience of Women and Children in Africa (Richard Roberts \& Benjamin Lawrence eds., 2012). 
this scholarship has focused solely on two contexts in which forced and servile marriages have taken place: in the context of war and other conflict situations, ${ }^{13}$ and when state courts have actively supported the practice. ${ }^{14}$ Allain demonstrates that the definition of slavery provided in the 1926 Slavery Convention and the 1956 Supplementary Convention on the Abolition of Slavery, the Slave Trade, and Institutions and Practices Similar to Slavery is the fundamental definition of slavery in international law. ${ }^{15}$ Furthermore, Allain posits that this definition encompasses a broad enough range of practices and circumstances to cover both legal slavery (and slavery as it exists today), including "servile" marriage. ${ }^{16}$ As such, the definitions provided in Article 1 (1) of the 1926 Slavery Convention ("Slavery is the status or condition of a person over whom any or all of the powers attaching to the right of ownership are exercised." $)^{17}$ and reproduced and augmented in Article 7(a) of the 1956 Supplementary Convention ("Slavery means, as defined in the Slavery Convention of 1926, the status or condition of a person over whom any or all of the powers attaching to the right of ownership are exercised, and 'slave' means a person in such condition or status") ${ }^{18}$ are of great benefit to the antislavery agenda because it allows for all forms of modern slavery to be recognized in international legal jurisprudence. These definitions can also be used to hold states responsible and individual enslavers liable for the enslavement of women even within the construct of the institution of marriage.

The 1948 Universal Declaration of Human Rights (UDHR) was the first international agreement that recognized the importance of consent in the

13. See Karine Bélair, Unearthing The Customary Law Foundations of "Forced Marriages" During Sierra Leone's Civil War: The Possible Impact of International Criminal Law on Customary Marriage and Women's Rights in Post-Conflict Sierra Leone, 15 Colum. J. Gender \& L. 551 (2006); Jeanelle Ferril, A Call for new Justice: Victims of Sexual Violence in Africa's Internal Conflicts, 4 FIU L. Rev. 333 (2008); Jennifer Gong-Gershowitz, Forced Marriage: A "New" Crime Against Humanity?, 8 NW. U. J. INT'L Hum. RTs. 53 (2009); Neha Jain, Forced Marriage as a Crime Against Humanity Problems of Definition and Prosecution, 6 J. INT'L CRIM. Just. 1013 (2008); Tamara F. Lawson, A Shift Towards Gender Equality in Prosecutions: Realizing Legitimate Enforcement of Crimes Committed Against Women in Municipal and International Criminal Law, 33 S. IL.. U. L.J. 181 (2009); Valerie Oosterveld, Lessons From the Special Court for Sierra Leone on the Prosecution of Gender-Based Crimes, 17 Am. U. J. Gender Soc. Pol'y \& L. 407 (2009); Amy Palmer, An Evolutionary Analysis of Gender-Based War Crimes and the Continued Tolerance of "Forced Marriage," 7 Nw. U. J. INT'L Hum. RTs. 128 (2009); Cecily Rose, Troubled Indictments at the Special Court for Sierra Leone the Pleading Of Joint Criminal Enterprise And Sex-Based Crimes, 7 J. InT'L CRIM. Just. 353 (2009).

14. Palmer, supra note 13, at 154 .

15. See Allain, The Definition of Slavery in International Law, supra note 12.

16. See id.; Jean Allain, The Law and Slavery: Prohibiting Human Exploitation 466-75 (2015).

17. Slavery Convention, adopted 25 Sept. 1926, art. 1(1), 60 L.N.T.S. 254; (entered into force 9 Mar. 1927).

18. Supplementary Convention on the Abolition of Slavery, supra note 2 . 
establishment of a marriage. ${ }^{19}$ The dual requirements that marriage should be entered into freely, and with full consent between men and women of full age is stipulated in Article 16 (1). No definition of "full age" is offered. Determination of a minimum age proved to be problematic since states had already codified different minimum age limits for marriage, and no agreement could be reached on a common minimum age. ${ }^{20}$

The provisions on servile marriage in the 1956 Supplementary Convention, eight years later, were the first provisions in international law that sought to proactively prevent forced marriage by requiring states to enact safeguards within their boundaries to ensure consent within marriage. ${ }^{21}$ The 1956 Convention was thereby the vehicle through which forced marriage found its way onto the international agenda. Article 1 of the 1956 Supplementary Convention reads:

Each of the States Parties to this Convention shall take all practicable and necessary legislative and other measures to bring about progressively and as soon as possible the complete abolition or abandonment of the following institutions and practices, where they still exist and whether or not they are covered by the definition of slavery contained in article 1 of the Slavery Convention signed at Geneva on 25 September 1926:

[. . . ]

(c) Any institution or practice whereby:

(i) A woman, without the right to refuse, is promised or given in marriage on payment of a consideration in money or in kind to her parents, guardian, family or any other person or group; or

(ii) The husband of a woman, his family, or his clan, has the right to transfer her to another person for value received or otherwise; or

(iii) A woman on the death of her husband is liable to be inherited by another person. $^{22}$

19. Universal Declaration of Human Rights, adopted 10 Dec. 1948, G.A. Res. 217A (III), U.N. GAOR, 3d Sess, art. 16(1), 16(2), U.N. Doc. A/RES/3/217A (1948): "Men and women of full age . . . have the right to marry and found a family. They are entitled to equal rights as to marriage, during marriage and at its dissolution." "Marriage shall be entered into only with the free and full consent of the intending parties."

20. Id.

21. Supplementary Convention on the Abolition of Slavery, supra note 2.

22. Id. art 1. Although termed a "status similar to slavery" at the time, these forms of subjugation are, in fact, forms of slavery consistent with the definition of slavery set forth by the Slavery Convention; United Nations Conference of Plenipotentiaries on a Supplementary Convention on the Abolition of Slavery, the Slave Trade and Institutions and Practices Similar to Slavery, Final Act and Supplementary Convention, U.N. Doc E/CONF.24/23 (4 Sept. 1956). 
Practices similar to slavery also include children under eighteen being delivered into forced labor.

Any institution or practice whereby a child or young person under the age of 18 years, is delivered by either or both of his natural parents or by his guardian to another person, whether for reward or not, with a view to the exploitation of the child or young person or of his labour. ${ }^{23}$

In order to control these practices, state parties "undertake to prescribe, where appropriate, suitable minimum ages of marriage, to encourage the use of facilities whereby the consent of both parties to a marriage may be freely expressed in the presence of a competent civil or religious authority, and to encourage the registration of marriages." ${ }^{24}$ Parties further undertake to criminalize acts of and involvement in slavery. No specific reference is made to child marriage or to the minimum age of a marriage. This reflects the absence of clear consensus in the international community at the time the treaty was concluded. Some of these states' legal systems often included a combination of the legal regime of the colonial ruler and traditional legal systems. Such multiple or plural legal systems, whether formal, religious, or traditional, continued to provide parallel and often conflicting provisions on child marriages for decades to come.

This matter is again addressed in the 1964 Convention on Consent to Marriage, Minimum Age for Marriage and Registration of Marriages. ${ }^{25}$ Article 1 sets the requirements for a legally entered marriage as full and free consent of both parties, with such consent to be expressed by them in person. ${ }^{26}$ The crucial factor of minimum age is left to states to determine, but may not be under fifteen years: state parties to the present Convention shall specify a minimum age for marriage ("not less than fifteen years" according to the nonbinding recommendation accompanying this Convention). ${ }^{27}$ No marriage shall be legally entered into by any person under this age except where a competent authority has granted a dispensation as to age, for serious reasons, in the interests of the intending spouses. ${ }^{28}$ An additional safeguard is

23. Id. art. $1(\mathrm{~d})$.

24. Id. art. 2.

25. Convention on Consent to Marriage, Minimum Age for Marriage and Registration of Marriages, adopted 7 Nov. 1962, G.A. Res. 1763 A (XVII) (entered into force 9 Dec. 1964).

26. Id. art. 1.

27. Id. art 2; Recommendation on Consent to Marriage, Minimum Age for Marriage and Registration of Marriages, opened for signature and ratification by UNGA Res. 2018 (XX), (1 Nov. 1965); A similar predicament can be detected in international efforts to regulate child soldiers. Here it was states such as the US advocating for the minimum age of fifteen instead of eighteen. See M.E. Olivier, Children in Armed Conflict: Draft Optional Protocol to the Convention on the Rights of the Child, 24 S.Afr. Y.B. INT'L L. 246 (1999).

28. $I d$. 
that marriages must be registered by the competent authority. ${ }^{29}$ It may be gleaned from these provisions that circumstances may exist where approval can be given for the marriage of an individual under fifteen years old. What would be regarded as sufficiently "serious reasons" is open to speculation.

This position was endorsed when the International Covenant on Civil and Political Rights (ICCPR) was adopted in 1966, requiring free and full consent for marriage between men and women of marriageable age, leaving the question of minimum age limitations to each of the parties to the Covenant. ${ }^{30}$ The Convention on the Elimination of All Forms of Discrimination against Women (CEDAW), adopted in 1979, mentions that the betrothal and the marriage of a child shall have no legal effect and that all necessary action shall be taken to specify a minimum age for marriage, and to make the registration of marriages in an official registry compulsory. ${ }^{31}$

Toward the end of the twentieth century, international focus turned to enhanced protection of the human rights of children as a particularly vulnerable group and a number of binding and nonbinding instruments were focused specifically on the rights of the child in all its dimensions. The Convention on the Rights of the Child (CRC) ${ }^{32}$ takes a comprehensive approach to the best interests of the child ${ }^{33}$ and places child rights firmly on the international agenda. ${ }^{34}$ This convention brings clarity to the elusive issue of minimum age by clearly defining a child as a person below the age of eighteen. The CRC recognizes various human rights of a child that will be violated in a forced marriage, such as the rights not to be separated from parents, ${ }^{35}$ but also freedom of expression, ${ }^{36}$ association, ${ }^{37}$ and arbitrary interference with a child's privacy and family. ${ }^{38}$ More specifically, it encapsulates: the right to protection from all forms of physical or mental violence, injury or abuse, maltreatment or exploitation, including sexual abuse, while in the care of parents, guardians, or any other person; ${ }^{39}$ the right to health

29. Id.

30. International Covenant on Civil and Political Rights, adopted 16 Dec. 1966, G.A. Res. 2200 (XXI), U.N. GAOR, 21st Sess., art. 23, U.N. Doc. A/6316 (1966), 999 U.N.T.S. 171 (entered into force 23 Mar. 1976) [hereinafter ICCPR].

31. Convention on the Elimination of All Forms of Discrimination Against Women, adopted 18 Dec. 1979, G.A. Res. 34/180, U.N. GAOR, 34th Sess., art. 16(2), U.N. Doc. A/34/46 (1980), 1249 U.N.T.S. 13 (entered into force 3 Sept. 1981) [hereinafter CEDAW].

32. Convention on the Rights of the Child, adopted 20 Nov. 1989, G.A. Res. 44/25, U.N. GAOR, 44th Sess., U.N. Doc. A/44/49 (1989), 1577 U.N.T.S. 3 (entered into force 2 Sept. 1990) [hereinafter CRC].

33. Id. art 3. In all actions concerning children the best interests of the child shall be a primary consideration.

34. The CRC has been ratified by all countries with the exception of the United States.

35. CRC, supra note 32 , art. 9(1).

36. Id. art. 13.

37. Id. art. 15.

38. Id. art. 16 .

39. Id. art. 19(1). 
and to access to health services; ${ }^{40}$ the right to be protected from harmful traditional practices; ${ }^{41}$ the right to education on the basis of equal opportunity; ${ }^{42}$ and the right to protection from all forms of sexual exploitation and sexual abuse. ${ }^{43}$ These provisions are set off by the provision that children belonging to an indigenous minority shall have the right to enjoy their own culture and religion. ${ }^{44}$ This provision implicitly recognizes the potential for conflict between cultural and religious practices and the convention's provisions. It echoes earlier treaty provisions from the International Covenant on Economic, Social and Cultural Rights (ICESCR) of $1966^{45}$ and the ICCPR ${ }^{46}$ that recognized the right to participate in and enjoy one's own cultural life.

\section{AFRICAN INSTRUMENTS REGULATING CHILD AND FORCED MARRIAGE}

The struggle for African independence from colonial rule went hand in hand with the quest to unite the continent or pan-Africanism. The pursuit of independence and an African identity found expression in the establishment of the Organization of African Unity (OAU) in 1963. The OAU adopted the African Charter on Human and Peoples' Rights (ACHPR), which presents a uniquely regional interpretation of human rights while endorsing the provisions of existing international instruments focused on the protection of women and children. ${ }^{47}$ The African child is brought into focus by the African Charter on the Rights and Welfare of the Child, adopted in 1990.48 This Charter again defines a child as a person below eighteen (Article 2) and reflects on the variety of children's human rights that will be violated in forced marriages as already protected by other international instruments. However, Article 21 is unique in that it protects children from harmful social and cultural practices, specifically including marriages and betrothals. ${ }^{49}$ The article states that "[c]hild marriage and the betrothal of girls and boys shall be prohibited and effective action, including legislation, shall be taken to

\footnotetext{
40. Id. art.24.

41. Id.

42. Id. arts. 28, 29.

43. Id. art. 34 .

44. Id. art. 30 .

45. International Covenant on Economic, Social and Cultural Rights, adopted 16 Dec. 1966, G.A. Res. 2200 (XXI), U.N. GAOR, 21st Sess., art. 15, U.N. Doc. A/6316 (1966), 993 U.N.T.S. 3 (entered into force 3 Jan. 1976) [hereinafter ICCPR].

46. Id. art. 27.

47. African Charter on Human and Peoples' Rights, adopted 27 June 1981, art. 18, O.A.U. Doc. CAB/LEG/67/3 Rev. 5, 1520 U.N.T.S. 217 (entered into force 21 Oct. 1986).

48. African Charter on the Rights and Welfare of the Child, adopted 11 July 1990, art. 21, O.A.U. Doc. CAB/LEG/24.9/49 (entered into force 29 Nov. 1999).

49. Id.
} 
specify the minimum age of marriage to be 18 years and make registration of all marriages in an official registry compulsory." 50

This provision highlights the danger that cultural practices endorsed by tradition may be in conflict with human rights standards. Moreover, Article 29 obligates parties to prevent abduction, sale, and traffic in children. ${ }^{51}$ These provisions are significant, as they make clear that state parties to the African Charter must prohibit marriages of those below the age of eighteen. Regulation and enforcement are left to individual state parties to resolve within their particular national legal systems. This position is regulated in more detail (including a preference for monogamy) by the Protocol to the ACHPR on the Rights of Women in Africa. ${ }^{52}$ With the latter two conventions, African states have made their agreed condemnation of child marriages unequivocal and official.

The picture presented by the various $U N$ and African treaty provisions identified above clearly answer the questions posed. Marriages not based on the full and free consent of both parties are considered a violation of human rights and a form of slavery. Those under the age of eighteen are not in a position to consent to marriage. States who are parties to these conventions should adopt legislation to enforce a minimum age (eighteen) and the required registration of marriages, as well as criminalize acts of slavery. Despite having these instruments in place, early and forced marriages still commonly occur across Africa. ${ }^{53}$ Public pressure from civil society organiza-

50. Id. art. 21(2).

51. Id.

52. Protocol to the African Charter on Human and Peoples Rights on the Rights of Women in Africa, adopted by the Second Ordinary Session of the Assembly of the Union, Maputo, 11 July 2003, art. 6, available at http://www.achpr.org/instruments/women-protocol/. Article 6 states:

States Parties shall ensure that women and men enjoy equal rights and are regarded as equal partners in marriage. They shall enact appropriate national legislative measures to guarantee that: no marriage shall take place without the free and full consent of both parties; the minimum age of marriage for women shall be 18 years; monogamy is encouraged as the preferred form of marriage and that the rights of women in marriage and family, including in polygamous marital relationships are promoted and protected; every marriage shall be recorded in writing and registered in accordance with national laws, in order to be legally recognised; the husband and wife shall, by mutual agreement, choose their matrimonial regime and place of residence; a married woman shall have the right to retain her maiden name, to use it as she pleases, jointly or separately with her husband's surname; a woman shall have the right to retain her nationality or to acquire the nationality of her husband; a woman and a man shall have equal rights, with respect to the nationality of their children except where this is contrary to a provision in national legislation or is contrary to national security interests; a woman and a man shall jointly contribute to safeguarding the interests of the family, protecting and educating their children; during her marriage, a woman shall have the right to acquire her own property and to administer and manage it freely.

53. See, e.g., UN Women Progress of the World's Women, 2011-2012, in Pursuit of Justice (2012), available at http://www.unwomen.org/ /media/headquarters/attachments/sections/ library/publications/2011/progressoftheworldswomen-2011-en.pdf. 
tions and political opinion are mounting to put an end to these practices. The Ouagadougou Declaration on Child Marriages adopted in 2003 by six African countries with high percentages of forced and underage marriages (Burkina Faso, Ghana, The Gambia, Mali, Nigeria, and Sudan) and the Forum on Marriage and the Rights of Women and Girls call for more stringent enforcement of treaty provisions and the addressing of conflicting laws. The Declaration calls upon governments and the $\mathrm{AU}$ to address the legal gaps created by plural legal systems by adopting:

a clear and unambiguous position on child and forced marriages and rectify the legislative loopholes between religious, customary and civil marriages, and sign the Protocol to the African Charter on Human and People's Rights on the Rights of Women in Africa and ensure that special measures are taken to help end this practice. ${ }^{54}$

The following table illustrates ratification of treaties by African states where child marriages are most prevalent. ${ }^{55}$

\begin{tabular}{|c|c|c|c|c|c|c|c|c|c|}
\hline Slavery Convention & $\begin{array}{c}\text { Mali } \\
\mathbf{x}\end{array}$ & $\underset{\mathbf{x}}{\text { Niger }}$ & Chad & CAR & Mozambique & $\begin{array}{c}\text { Cameroon } \\
\mathbf{x}\end{array}$ & $\begin{array}{c}\text { Ethiopia } \\
\mathbf{x}\end{array}$ & $\underset{\mathbf{x}}{\text { Zambia }}$ & $\begin{array}{c}\text { Guinea } \\
\mathbf{x}\end{array}$ \\
\hline $\begin{array}{l}\text { Consent to Marriage } \\
\text { Convention }\end{array}$ & $\mathrm{x}$ & $\mathbf{x}$ & & & & & & & $\mathbf{x}$ \\
\hline ICCPR & $\mathbf{x}$ & $\mathbf{x}$ & $\mathbf{x}$ & $\mathbf{x}$ & $\mathbf{x}$ & $\mathbf{x}$ & $\mathbf{x}$ & $\mathbf{x}$ & $\begin{array}{c}X \\
\text { r48(1) }\end{array}$ \\
\hline CEDAW & $\mathbf{x}$ & & $\mathbf{x}$ & $\mathbf{x}$ & & $\mathbf{x}$ & $\begin{array}{c}X \\
\text { r 29(1) }\end{array}$ & $\mathbf{x}$ & $x$ \\
\hline CRC & $\begin{array}{c}x \\
\text { r } 16\end{array}$ & $\mathbf{x}$ & $\mathbf{x}$ & $\mathbf{x}$ & $\mathbf{x}$ & $\mathbf{x}$ & $\mathbf{x}$ & $\mathbf{x}$ & $\mathbf{x}$ \\
\hline ACHPR & $x$ & $x$ & $x$ & $x$ & $x$ & $x$ & $x$ & $x$ & $x$ \\
\hline $\begin{array}{l}\text { African charter on } \\
\text { rights of the child }\end{array}$ & $\mathrm{x}$ & $\mathrm{x}$ & $\mathrm{x}$ & $\mathrm{s}$ & $\mathrm{x}$ & $\mathrm{x}$ & $\mathrm{x}$ & $\mathrm{x}$ & $\mathrm{x}$ \\
\hline $\begin{array}{l}\text { Protocol on rights of } \\
\text { women in Africa }\end{array}$ & $\mathrm{x}$ & s & $\mathrm{s}$ & s & $x$ & $x$ & $\mathrm{~s}$ & $x$ & $x$ \\
\hline
\end{tabular}

Key:

$x$ - States are a party to the convention through ratification or accession

s- Signature (Needs to be followed by ratification before a state can be regarded as a party.)

r- Reservations excluding certain treaty provisions. Reservations may not be contrary to object and purpose of convention.

The above table indicates the African states that have universally ratified the ICCPR, CRC, and the ACHPR. The older convention (slavery) is not ratified by three out of the ten states, while the Consent to Marriage Convention

54. The Ouagadougou Declaration on Child Marriages (2003), available at http://www. wluml.org/node/1211.

55. See Slavery Convention, supra note 17; Convention on Consent to Marriage, Minimum Age for Marriage and Registration of Marriages, supra note 25; ICCPR, supra note 30; CEDAW, supra note 31; CRC supra note 32; See also African Commission on Human and Peoples' Rights, Ratification Table: African Charter on Human and Peoples' Rights (2016), available at http://www.achpr.org/instruments/achpr/ratification/; African Union, ACRWC Ratifications Table, available at http://pages.au.int/acerwc/pages/acrwc-ratifications-table. 
has only been ratified by three states. This gap in ratifications is compensated for by comprehensive ratification of the more recent CRC by all the states concerned and, bar one (Central African Republic), ratification of the African Child Convention. Generally speaking, these states made very few reservations to the treaties; thereby, opting out of only a small number of treaty provisions. ${ }^{56}$ States seem to be more reluctant to commit themselves to protection of women in Africa. The Central African Republic adopted a cautious approach by not committing itself to conventions that run contrary to domestic practices. The reasons for this approach require further research.

\section{NATIONAL TRENDS}

A high number of child marriages appear to take place in West and Central Africa where two out of five girls are child brides, according to a 2012 publication by the United Nations Population Fund. ${ }^{57}$ The United Nations Children's Emergency Fund (UNICEF) provides another perspective. ${ }^{58}$ This agency surveyed women aged twenty to twenty-four across the world and, if they were married, recorded their age at the time of their first marriage. UNICEF aggregated such data to show the proportion of women who were married or in a union before age fifteen, and those who were married or in a union at age fifteen or after, but before age eighteen. ${ }^{59}$ According to UNICEF, 41 percent of girls in West and Central Africa were married before age eighteen, and 16 percent were married before age fifteen. For Sub-Saharan Africa, the figures were 39 percent and 13 percent respectively. For Eastern and Southern Africa, 38 percent were thought to be married before age eighteen, and 10 percent before age fifteen. ${ }^{60}$

\section{REASONS WHY EARLY AND FORCED MARRIAGES OCCUR IN THESE STATES}

There are many reasons why child and forced marriage occur at high rates in the African states listed above. Although contributing factors are often related, this article does not focus on the obvious socioeconomic reasons, such as poverty and gender inequality, but rather assess why this practice,

\footnotetext{
56. See id.

57. United Nations Population Fund (UnfPa), Marrying Too Young End Child Marriage 27 (2012).

58. UNICEF, Child Protection From Violence, Exploitation and Abuse, Child Marriage, available at http://www.unicef.org/protection/57929_58008.html.

59. See UniCef, Ending Child Marriage: Progress and Prospects (2013).

60. Id.
} 
so clearly a violation of the states' international obligations, manages to occur and flourish within its domestic legal systems.

The demarcation of Africa into states by former colonial powers did not take account of natural geographical borders, and as a result, divided indigenous communities. When African states became independent, they decided to retain colonial boundaries, despite how arbitrarily drawn by imperial powers, according to the international legal principle of uti possidetis. ${ }^{61}$ The OAU regarded this as the wisest course of action to prevent the disruption that would result from redrawing boundaries based on ethnicity. ${ }^{62}$ Consequently, modern African states are multicultural societies with various legal systems. ${ }^{63}$ International law recognizes and protects different African cultures and traditions. However, these practices take many forms, some of which may include practices such as female genital cutting and child marriage, which are clear violations of both $U N$ and $A U$ conventions.

Despite being party to international instruments prohibiting child and forced marriages as well as the existence of implementing national legislation, states suffering from high percentages of child and forced marriage seldom have adequate legal and bureaucratic frameworks to enforce laws. A national legal framework should not only prohibit child and forced marriages (including legislating penalties for violations), but it should also provide an infrastructure to correctly reflect the date and registration of marriages. Inadequate legal frameworks, however, tend to exist alongside customary and religious laws that condone the practice. ${ }^{64}$ The reality is that society observes a plurality of legal rules, which can impact both legal certainty and the rule of law. Dominance of traditional practices is more prevalent in rural areas. UNICEF statistics indicate that the proportion of women married by the age of eighteen tends to be higher in rural than in urban areas. ${ }^{65} \mathrm{UNICEF}$ also found that belonging to a minority religious or ethnic group is also a significant predictor of child marriage in some countries. ${ }^{66}$

\section{STATE PRACTICE ON CHILD AND FORCED MARRIAGES}

What is the level of implementation and enforcement of the relevant treaty provisions on child and forced marriage by states? Ideally, this study would

61. See George N. Barrie, Uti Possidetis Versus Self-Determination and Modern International Law: In Africa the Chickens are Coming Home to Roost, J. S. Afr. L. 451 (1988).

62. The principle of uti possidetis was endorsed by the International Court of Justice. See Frontier Dispute (Burk. Faso/Mali), Judgment 1986 I.C.J. 554,565, If 20 (22 Dec.).

63. G.J. van Niekerk, Legal Pluralism, in Introduction to Legal Pluralism in South Africa, supra note 7 , at 3 .

64. Unicef, Early Marriage A Harmful Traditional Practice: A Statistical Exploration 4 (2005).

65. Id. at 5 .

66. Id. at 26 . 
include a full reference to legislation and case law in force in the nine African states identified above that deal with slavery, forced marriage, and underage marriage, in order to establish to what extent the states have given effect to their international obligations. Unfortunately, these sources are not readily available. Instead, available material on three of those countries: Chad, Mali, and Niger serve to illustrate the problem posed by forced and child marriages and the influence of legal pluralism on attempts to regulate these issues. The information on Chad and Mali is sourced from UN treaty monitoring bodies and legislation that is electronically available. The reports from the official treaty monitoring bodies serve as reliable sources because they respond to states' reports on the level of implementation and related problems experienced in a given state. In the case of Niger, a court judgment illustrating national enforcement will be considered. Although incomplete, this information underlines concerns about effective legislation against child and forced marriages.

\section{A. Chad}

In 2011, as required by CEDAW, Chad presented a report to the Committee on the Elimination of Discrimination against Women on measures taken to give effect to the provisions of the Convention. ${ }^{67}$ In its concluding observations, the Committee highlighted the problems created by traditional law as well as forced marriages. ${ }^{68}$ The Committee expressed its concern about the lack of clarity with respect to the actual status of customary and religious law vis-à-vis national law, its impact on the effective incorporation of the Convention in the national legislation and on its effective implementation in the state party. This was due to the strong patriarchal character of Chadian society, as well as the guarantor role of the traditions and customs of the country constitutionally granted to traditional leaders. ${ }^{69}$

The Committee made the following recommendations:

a) To raise awareness on the precedence of national law over customary law and of the Convention over national law, within the judiciary, and among traditional and religious leaders;

67. Concluding Observations of the Committee on the Elimination of Discrimination Against Women for Chad, U.N. GAOR, Comm. on the Elimination of Discrimination against Women, 50th Sess., U.N. Doc. CEDAW/C/TCD/CO/1-4 (4 Nov. 2011).

68. Id

69. Id. According to paragraph one of the report the Committee considered the combined initial to the fourth periodic report of Chad (CEDAW/C/TCD/1-4) at its 1009th and 1010th meetings, 12 Oct. 2011 (see CEDAW/C/SR.1009, 1010). The Committee's lists of issues and questions are contained in CEDAW/C/TCD/Q/4, CEDAW/C/TCD/Q/4/Add.2, and the responses by Chad are contained in CEDAW/C/TCD/Q/4/Add.1. 
(b) To carry out a comprehensive review process of its legislation with a view to, inter alia, repealing existing discriminatory provisions against women within customary, religious and modern laws and guaranteeing that these bodies of law are harmonized with the Constitution and the Convention; and set up a clear time frame for the completion of such review process. ${ }^{70}$

The Committee was also concerned about the existence of a combination of customary, religious, and modern marital laws, which contain discriminatory elements against women. In particular, it expresses its concern about "the persistence of early marriages, despite its prohibition under article 9 of the Act on reproductive health (2002)." ${ }^{\prime 71}$

The Committee called on Chad to raise "the minimum age of marriage for women to 18 years, guarantee . . . equal inheritance and succession rights to women and recognize . . . the full legal capacity of women, with a view to bringing it in line with the Convention."72 The Committee also urged Chad to undertake awareness-raising activities throughout the country on the negative effects of early marriages for girls, highlighting in particular the long-term effect on women with regard to the enjoyment of their rights to health and to education. ${ }^{73}$

The CEDAW report on Chad's implementation of women's rights encapsulates the tension between customary law vis-à-vis national and international law, when it comes to marriages. Implementation of legal requirements that run contrary to traditional laws are especially problematic in patriarchal societies, where the role of traditional leaders are constitutionally protected. The Committee gave a clear indication of the appropriate hierarchy of norms: customary law should be subordinate to national law and national law subordinate to the Convention. The continued occurrence of child marriage under customary law calls for an official response from Chad to address the problem.

\section{B. Mali}

Despite having officially ended slavery in 1960, Mali has yet to criminalize slavery. ${ }^{74}$ The Constitution of the Republic of Mali has all the elements one would expect in a modern constitution. The constitution recognizes

70. Concluding Observations of the Committee on the Elimination of Discrimination Against Women for Chad, supra note 67, at $913(\mathrm{a})(\mathrm{b})$.

71. Id. ब 42.

72. Id. ๑ 43(a).

73. Id. ๆ 43(c).

74. Ivan Broadhead, Malians Call for Criminalization of Slavery, Volce OF AMERICA, 8 Aug. 2013, available at http://www.voanews.com/content/malians-call-for-criminalization-ofslavery/1725960.html. 
the individual rights of all Malians including: the right to liberty, ${ }^{75}$ freedom, and equality; ${ }^{76}$ it has a constitutional court to oversee the constitutionality of governmental action and law; and it recognizes the superiority of ratified and published treaties over Mali's national law. ${ }^{77}$ Despite this provision, the CEDAW Committee points out that Mali's national legislation does not provide sanctions for acts of discrimination based on sex or remedies for victims of such acts. ${ }^{78}$ The Committee is concerned about,

[T] he persistence of discriminatory provisions that deny women equal rights with men concerning issues related to the transmission of nationality, marriage and family relations and access to land. Such discriminatory provisions include: a younger marriageable age for women ( 15 years old) than for men (18 years old); termination of maintenance support awarded to an ex-wife on grounds of immoral behaviour; in the event of divorce, restitution to the husband of benefits given to his wife and limitations on the exercise of parental authority by a surviving mother; and discrimination against women concerning their customary land rights. $^{79}$

\section{Niger: The Koraou judgment}

The Koraou judgment is an example of how an African interstate court did not shy away from taking on the issues of forced marriages and slavery. Slavery within marriage in Niger was considered before the Economic Community of West Africa (ECOWAS) Community Court of Justice (ECCJ) in 2008 in a well-documented, landmark decision, Hadijatou Mani Koraou v. Niger. ${ }^{80}$

On 27 October 2008, the ECCJ determined that the Republic of Niger had failed to protect twenty-four year-old Hadijatou Mani Koraou from slavery. ${ }^{81}$ Hadijatou Mani Koraou was born in 1984 into an established slave class. Her mother was a slave and Hadijatou inherited her mother's slave status. Like all slaves in Niger, she could be inherited, sold, and made to work without pay. At the age of twelve, she was sold for $\$ 400$ by her mother's owner to a man named El Hadj Souleymane Naroua, who brought her into his household as a Sadaka or "fifth wife." The fifth wife has no status and remains essentially a sex and domestic service slave for her master. Any children she bears remain his property. Sadaka, or wahiya, according to the ECOWAS Court:

\footnotetext{
75. Const. Mali, art. 1

76. Id. art. 2

77. Id. art. 116 .

78. Concluding Observations of the Committee on the Elimination of Discrimination Against Women for Mali, U.N. GAOR, Comm. on the Elimination of Discrimination against Women, 34th Sess., 9 10, U.N. Doc. CEDAW /C/MLI/CO/3 (3 Feb. 2006).

79. Id. I 11.

80. Hadijatou Mani Koraou v. The Republic of Niger, App. No. ECW/CCJ/APP/08/08, Judgment No. ECW/CCJ/JUD/06/08 (27 Oct. 2008).

81. Id. ๆ 9 .
} 
[C]onsists of acquiring a young girl, generally under the conditions of servitude, for her to serve both as domestic servant and concubine. A woman slave who is bought under such conditions is called a sadaka, or 'the fifth wife,' that is to say, a woman outside those legally married (the number of which cannot exceed four, in accordance with the recommendations of Islam) . . . The sadaka generally carries out the domestic chores and caters for the 'master.' The latter can, at any time, during the day or night, engage her in sexual relations. ${ }^{82}$

Her master had four wives and seven other Sadaka. For nine years, she was kept as a slave within his household, where she performed domestic chores and was repeatedly raped. In order to elevate her status from Sadaka to wife, Naroua gave her a "liberation certificate" in 2005. Later produced in court, the certificate stated that "I, El Hadj Souleymane Naroua have liberated Mme Hadijatou Koreau on this day 18 August and she is now free and is no-one's slave." 83 The certificate was signed by "the chef du village," "the master," and the "beneficiary." When she attempted to leave, her master explained that she was not free to leave after all; according to her master, she was and remained his wife. She eventually fled and married another man, at which point, Naroua complained to law enforcement. Officials then prosecuted and jailed her for bigamy.

Hadijatou Mani Korau's case is seminal, but virtually singular, and its success pivots on the fact that the courts in Niger were complicit in her enslavement. State action was, therefore, more than clear. After her complaint was considered, the ECCJ condemned Niger for failing to protect Koraou from enslavement. Created in $1996^{84}$ to adjudicate interstate human rights litigation, the court was empowered by a supplementary protocol adopted in 2005 to hear individual human rights cases. ${ }^{85}$ The supplementary protocol made the court a directly accessible forum for West African litigants. ${ }^{86}$ The court has no requirement that local remedies must be exhausted before receiving a case, and its judgments are directly enforceable in national legal systems of states. ${ }^{87}$ In this particular case, the judgment not only found an affirmative obligation for states to protect citizens against slavery, but also that Niger had to pay ten million Central African Francs (CFA) to the victim. ${ }^{88}$

82. Id. ๆ 9-10.

83. Id. ศ 11.

84. By Protocol A/P1/7/91 Relating to the ECOWAs Community Court of Justice (adopted 6 July 1991) (entered into force 5 Nov 1995), available at http://www.courtecowas.org/ site2012/pdf_files/protocol.pdf.

85. Supplementary Protocol A/SP.1/01/05 Amending Protocol A/P1/7 /91, arts. 9, 10, available at http://www.courtecowas.org/site2012/pdf_files/supplementary_protocol.pdf.

86. Horace S. Adjolohoun, The ECOWAS Court as a Human Rights Promotor/ assessing Five Years' Impacts of the Koraou Slavery Judgment, 31 Netherlands Q. Hum. Rts. 343 (2013).

87. Id. at 344 .

88. Id. at 346, n.24. 
The scholar Adjolohoun considers the impact that this judgment has made on the domestic system of Niger where, despite the criminalization of slavery from 2003, thousands remain enslaved. ${ }^{89} \mathrm{He}$ finds that effective enforcement of the law and effective domestic remedies are still lacking due to the following factors: slavery-related matters are not handled with the required diligence, as required by a circulaire issued by the Ministry of Justice, ${ }^{90}$ inadequate knowledge of antislavery legislation by investigating officers; ${ }^{91}$ and failure to "properly characterize" the facts of the case due to cultural or religious bias of the police or gendarmerie..$^{92}$ In fact, slavery is denied at the highest state level and antislavery activists have been arrested..$^{93}$

The effect of this decision in Mali, where thousands continue to be enslaved, remains to be seen. It is worth noting, however, that the American Bar Association established a law clinic in 2011 with a local antislavery NGO to provide free legal advice as well as to train lawyers, police, prosecutors, and judges on handling slavery cases. ${ }^{94}$

\section{PLURAL LEGAL SYSTEMS}

As indicated above, child marriage is a form of slavery as well as a clear violation of international law. Despite the fact that most of the Sub-Saharan African states subscribe to these international instruments and have outlawed slavery in their national laws, the problem persists. Attitudes stemming from traditional and religious beliefs that tolerate or even encourage these practices may be at fault. In many contexts, these practices are in line with customary law.

This raises the question: which legal rules do citizens acknowledge as binding-those coming from a supposedly democratic or undemocratic legislature, or those they believe to be endorsed by religion or custom? Human rights instruments rightfully acknowledge the validity and value of diverse cultures, religions, and traditional practices while condemning those practices that are considered "harmful," broadly defined. The preservation of minority rights, particularly culture and a traditional way of living, is also well documented in international law. ${ }^{95}$ What, however, is the outcome when legal systems conflict, particularly with regard to "traditional" matters of home and family? Given the intrinsic legitimacy, or popular acceptance, that

89. Id. at 352 .

90. Id.

91. Id.

92. Id.

93. Id. at 353.

94. Id. at 366.

95. Minority rights are protected inter alia by the ICCPR, ICESCR, CEDAW, and CRC. 
traditional legal systems might have among groups within a larger society, challenging such beliefs may have far reaching consequences, both for the individual and for the larger community.

Plural legal systems reflect situations where different legal systems are observed within a single sovereign state or one socioeconomic space: customary rules remain operational in a modern context alongside statutory law. According to van Niekerk, a scholar who comments on customary law in a South African context, legal pluralism owes its existence to prevailing cultural pluralism and can be interpreted in either a narrow or a broad sense. Narrowly interpreted, legal pluralism refers to a "dual systems" approach, where European and Western law runs parallel to traditional forms of law in a single society and both are officially recognized by the state. Provided it is consistent with society's wider views of what is moral and in the public interest, customary law is generally accepted by the state as legitimate and binding. This approach, however, often fails to explain the social realities in modern African states. ${ }^{96}$ The broad interpretation of legal pluralism refers to a factual situation that exists in a society where various legal systems are observed. ${ }^{97}$ Von Benda-Beckman offers some conceptual arguments on legal pluralism in a wider sense: plural legal orders are "based on different sources of ultimate validity and maintained by forms of organization other than the state." ${ }^{\prime 98}$ These situations, he suggests, call for analysis of empirical situations instead of conceptual a priori's and stereotyping. ${ }^{99}$ Social phenomena relating to harmful traditional practices may have a legal character, but may also be nonlegal. Von Benda-Beckmann suggests that the concept of law is not linked to the state by definition, and is broad enough to include plural legal systems. ${ }^{100} \mathrm{He}$ acknowledges that this idea has anthropological roots, and will not be shared by judges who will be bound to apply a positivist conceptualization of law. ${ }^{101}$ He argues that asymmetrical power relations between the colonial ruler and the indigenous minority supported the development of legal pluralism in colonial societies. ${ }^{102}$ Von Benda-Beckmann also mentions that some legal pluralists believe that rules should vary based on the circumstances, including in the instance of marriage. ${ }^{103}$

\footnotetext{
96. van Niekerk, supra note 63 , at 4 .

97. Id. at 4. Although these comments are given in a South African legal context, observations on legal pluralism are equally applicable to other African states where cultural pluralism prevails.

98. Franz von Benda-Beckmann, Who's Afraid of Legal Pluralism, 34 J. Legal Pluralism \& UnOFFICIAL L. 37, 37 (2002).

99. Id. at 47 .

100. Id. at 40 .

101. Id. at 41 .

102. Id. at 60 .

103. Id. at 62. Von Benda- Beckmann refers to West Sumatra where there are three different legal systems: adat, Islamic law, and state law-all having different provisions.
} 
Elements of both narrow and deep legal pluralism may be detected in states where forced marriages occur. These marriages may take place under customary rules that are either officially recognized by the state or factually observed and tolerated. The additional influence of international law on a dual system scenario becomes further complicated because international law presents a third level of legal rules. International law addresses this situation by expecting states to bring their national law in line with treaty obligations, when they become party to a treaty. Governments should either address conflicting practices based on custom, or enter reservations excluding certain practices from falling under the treaty. This use of reservations has been employed by Muslim states to exclude treaty provisions conflicting with the Islamic Sharia. ${ }^{104}$ The factual situation as observed under deep pluralism will be more difficult to address since customary law is not officially regulated. Therefore, it will also be more difficult to regulate offensive practices.

The question of local acceptance or legitimacy of legal rules is crucial to address the problem of forced and child marriages. In a study of the rule of law in Africa, Abioye highlighted that legal rules have very little chance of being complied with in societies where they do not enjoy grassroots legitimacy. ${ }^{105}$ Legitimacy can be measured by the extent that legal rules reflect the identity, perceived self-interests, and expectations of those they seek to bind. ${ }^{106}$ Mainstream national law may not have infiltrated the belief system of traditional, often minority groups, and traditional systems remain operational on a day-to-day basis. Julie Endy describes plural legal systems as a failure of legal penetration that compromises the rule of law. ${ }^{107}$ With reference to Guatemala, Endy argues that de facto existence of plural legal systems benefit indigenous populations, specifically in relation to developing alternative methods of dispute resolution. ${ }^{108}$ Given that Africa has responded to the challenge to regulate forced and child marriages through African treaties, it will be difficult to argue that these provisions should not speak to traditional African societies. The onus is now on national governments to facilitate both the legal infiltration of customary law, and dissemination of treaty provisions amongst traditional societies. This would require both legal reform and cultural adjustments to change nonlegal rules.

104. For a list of reservations, see UN Treaty Collection, Multilateral Treaties Deposited with the Secretary-General, available at https://treaties.un.org/pages/participationstatus.aspx.

105. Funmilola Tolulope Abioye, Rule of Law in English Speaking African Countries: The Case of Nigeria and South Africa 15-25 (LL.D. Thesis University of Pretoria, Feb. 2011).

106. Michèle Emily Olivier, Die Relatiwiteit van Menseregte met Spesifieke Vewysing na Tanzanie en Zambie 34 (M.A. Thesis, Rand Afrikaans University, 1990).

107. Julie Endy, Supporting Parallel Legal Systems as a Means of Improving Access to Justice in Guatemala, Law and Justice in the America Working Paper Series 1 (2007).

108. Id. 


\section{MEASURING THE RELATIONSHIP BETWEEN PLURAL LEGAL SYSTEMS AND CHILD MARRIAGE}

As noted above, the idea of a relationship between plural legal systems and child and forced marriage is not new. However, this assertion has never been empirically tested. A recent compilation of data on contemporary forms of slavery by the Global Slavery Index ${ }^{109}$ has made possible a database of 167 countries recording human rights violations and risks. As noted above, each year UNICEF assembles and disseminates information about child marriage around the world. These data sources provide estimates of the percentage of women, aged twenty to twenty-four, who were married or in a union before the age of eighteen. Using this data, UNICEF creates an ordinal child marriage measure for each country on a scale from one to five, where one equals the least number of child marriages and five equals the most child marriages. This measure of child marriage as a proxy for adult forced marriage is used for two reasons. First, no uniform measure of forced marriage of adults currently exists. Second, it is assumed that high levels of child marriage and early marriage will be correlated with forced adult marriage.

Types of plural legal systems that were described above can be identified and quantified through another recognized source. The CIA World Factbook records the type of legal system in place for each country listed. The entry for the country of Afghanistan, for example, reads, "mixed legal system of civil, customary, and Islamic law." ${ }^{\prime 10}$ In comparison, the legal system of the United Kingdom is described as, "common law system; has nonbinding judicial review of Acts of Parliament under the Human Rights Act of 1998."111 In other words, it is not a mixed system. In compiling the data for this research, any country with a mixed legal system and a mention of traditional, customary, or Islamic law is recorded as having a plural legal system.

When these two variables are mapped by country, an apparent pattern emerges. Map 1 shows the distribution of the prevalence of child marriage, there are clearly regions in which this violation is more pronounced. Globally, the countries reported to have the highest incidence of child marriage are Bangladesh, Chad, Ethiopia, Guinea, Malawi, Mali, Mozambique, Nepal, and Niger. ${ }^{112}$ These are the countries shown with the darkest shading in the map below. Countries with the next highest level of child marriage are shown in lighter shading.

109. Global Slavery Index, Walk Free Foundation, Perth Australia, available at http://www. globalslaveryindex.org.

110. See Central Intelligence Agency, The World Factbook, available at https://www.cia.gov/ library/publications/resources/the-world-factbook/geos/af.html. .

111. Id.

112. Girls Not Brides, Child Marriage Around the World, available at http://www.girlsnotbrides. org/where-does-it-happen/. 


\section{Child Marriage}

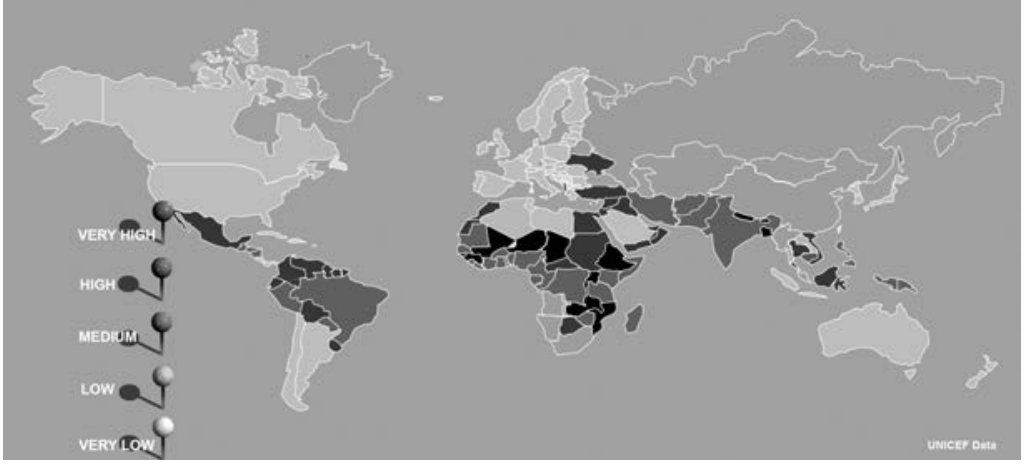

Map 1-Geographical Prevalence of Child Marriage

Plural legal systems are not recorded in degree but as a dichotomous variable. Map 2 shows countries that have plural legal systems. As can be seen, a majority of those countries recorded as having a plural legal system are in Africa, but countries with plural legal systems also include, among others, India, Pakistan, Bangladesh, Afghanistan, Indonesia, Iran, Iraq, Albania, Cambodia, Ireland, and Israel.

\section{Parallel Legal Systems}
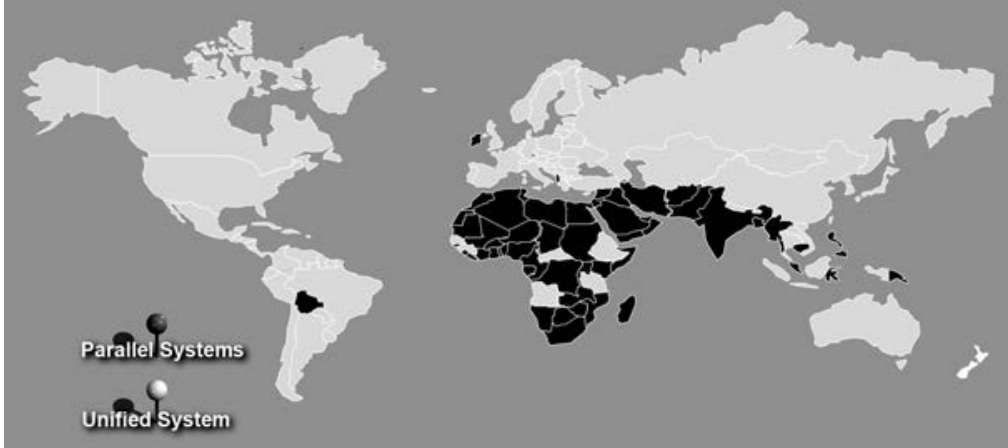

Map 2-Countries with Plural Legal Systems 
A further test of this relationship is to measure the statistical significance of the probability that child marriage occurs within a plural legal system. Using the UNICEF child marriage variable as a dependent variable (ranked on a scale from one to five, where one represents very low levels of child marriage and five represents the highest levels of child marriage), and using the plural legal systems variable (where one represents the presence of a plural legal system and zero represents its absence) as the independent variable, the following results were obtained and shown in Table 1.

For 162 countries, the relationship between child marriage and plural legal systems is significant, measured by the $\mathrm{Chi}^{2}$ statistic as greater than 0.00001 .

Table 1 - Ordered Logit Model, Child Marriage and Plural Legal Systems

\begin{tabular}{r|cccccc}
\hline \hline Childmar & Odds Ratio & Std. Err. & $\mathrm{z}$ & $\mathrm{P}>|\mathrm{z}|$ & \multicolumn{2}{|c}{ [95\% Conf. Interval] } \\
\hline Plural & 4.327521 & 1.304403 & 4.86 & 0.000 & 2.397009 & 7.812833 \\
\hline /cut1 & -.2757436 & .2078558 & & & -.6831335 & .1316463 \\
/cut2 & .5287656 & .2118798 & & & .1134887 & .9440424 \\
/cut3 & 1.777046 & .2524713 & & & 1.282211 & 2.271881 \\
/cut4 & 3.723325 & .4004133 & & & 2.938529 & 4.50812
\end{tabular}

There are two key points to be made from this statistical test. The first is that the logit regression results suggest that the odds of being ensnared in child marriage are about four times greater in the presence of a plural legal system, other things being equal. The second key point is that, while this is shown to be a statistically significant relationship, the strength of that relationship is weak as measured by the pseudo $R^{2}$ at .0513 . This suggests that other factors are more important in determining the prevalence of child and forced marriages than simply the presence of plural legal systems. This second point is not surprising, as it indicates the complexity of the interrelation of cultural influences, such as gender roles and religion, and that of governance factors. Statistically, this is referred to as multicollinearity, and the usefulness of regression analysis is that it allows us to examine the independent effects of a factor such as plural legal systems. ${ }^{113}$ In the future, we hope to bring other determinant factors to the statistical analysis of forced and child marriage.

113. Sarker Obaida Nasrin and K. M. Mustafizur Rahman, Factors Affecting Early Marriage and Early Conception of Women: A Case of Slum Areas in Rajshahi City, Bangladesh, 4 INT'L J. SOC'GY \& ANTHRPOL'Gr 54 (2012). 


\section{CONCLUSIONS AND INDICATED FUTURE RESEARCH}

There is a clear and statistically significant relationship between child marriage and the presence of plural legal systems. Results suggest that the same relationship exists for adult forced marriage, but currently there is a lack of data to test this empirically. As noted above, there are complex interrelations between customary laws, national laws, and international conventions and treaties. The key aim of this article was to illuminate this interrelationship, and point to areas where it has failed to protect girls and women from forced marriages. Also, appropriate laws can protect girls and women, when there is sufficient political will and consensus to do so. At best, this study is offered as an initial, exploratory work that will serve to open this area of inquiry. Clearly, it raises more questions than it answers.

For example, this article provided a review of some of the legal systems in Africa that struggle with the contrasting aims of customary versus national laws, much more insight is needed in the application of plural legal systems in each country-including those countries outside of Africa that have plural systems. Additionally, forced marriage, while clearly rejected by international conventions, continues to be commonplace around the world. Forced marriage, however, remains largely unmeasured and often unregulated, or even mentioned, in national laws. This leads to several questions: How do we understand this phenomenon, how do we define it legally, and how might it be operationalized for further social scientific and human rights study? Corruption and the absence of the rule of law is thought to be a significant predictor of the prevalence of slavery, but how might the presence of plural legal systems, particularly where the rule of law is weakened, be an equally significant predictor of forced marriage slavery? What other factors have the greatest explanatory power in predicting the presence of child and forced marriage in different countries? Answers to these questions are crucial to the development of appropriate and efficient policies that protect the lives of girls and women. 